\title{
Article \\ Genome-Wide Identification of Genes Involved in Acid Stress Resistance of Salmonella Derby
}

\author{
Dan Gu 1,2,3,4, Han Xue 1,2,3,4, Xiaohui Yuan 1,2,3,4 , Jinyan Yu 1,2,3,4, Xiaomeng Xu 1,2,3,4, Yu Huang 1,2,3,4, \\ Mingzhu Li 1,2,3,4, Xianyue Zhai 1,2,3,4, Zhiming Pan 1,2,3,4, Yunzeng Zhang 1,2,3,4,* and Xinan Jiao 1,2,3,4 (iD) \\ 1 Jiangsu Co-Innovation Center for Prevention and Control of Important Animal Infectious Diseases \\ and Zoonoses, Yangzhou University, Yangzhou 225009, China; 006491@yzu.edu.cn (D.G.); \\ xhxxdjy@163.com (H.X.); xiaohui_yuan@outlook.com (X.Y.); eve_421@163.com (J.Y.); \\ xiao1997710@163.com (X.X.); huangyu20212021@163.com (Y.H.); lmzdyx1997@163.com (M.L.); \\ DX120180123@yzu.edu.cn (X.Z.); zmpan@yzu.edu.cn (Z.P.); jiao@yzu.edu.cn (X.J.) \\ 2 Jiangsu Key Laboratory of Zoonosis, Yangzhou University, Yangzhou 225009, China \\ 3 Joint International Research Laboratory of Agriculture and Agri-Product Safety of the Ministry of Education, \\ Yangzhou University, Yangzhou 225009, China \\ 4 Key Laboratory of Prevention and Control of Biological Hazard Factors (Animal Origin) for Agrifood Safety \\ and Quality, Ministry of Agriculture of China, Yangzhou University, Yangzhou 225009, China \\ * Correspondence: yzzhang@yzu.edu.cn
}

check for updates

Citation: Gu, D.; Xue, H.; Yuan, X.; Yu, J.; Xu, X.; Huang, Y.; Li, M.; Zhai, X.; Pan, Z.; Zhang, Y.; et al.

Genome-Wide Identification of Genes Involved in Acid Stress Resistance of Salmonella Derby. Genes 2021, 12, 476. https://doi.org/10.3390/genes 12040476

Academic Editor: Ir. Peter van Baarlen

Received: 27 February 2021

Accepted: 23 March 2021

Published: 25 March 2021

Publisher's Note: MDPI stays neutral with regard to jurisdictional claims in published maps and institutional affiliations.

Copyright: (c) 2021 by the authors. Licensee MDPI, Basel, Switzerland. This article is an open access article distributed under the terms and conditions of the Creative Commons Attribution (CC BY) license (https:/ / creativecommons.org/licenses/by/ $4.0 /)$.
Abstract: Resistance to and survival under acidic conditions are critical for Salmonella to infect the host. As one of the most prevalent serotypes identified in pigs and humans, how $S$. Derby overcomes acid stress remains unclear. Here, we de novo sequenced the genome of a representative $S$. Derby strain $14 \mathrm{~T}$ from our $S$. Derby strain stock and identified its acid resistance-associated genes using Tn-seq analysis. A total of 35 genes, including those belonging to two-component systems (TCS) (cpxAR), the CRISPR-Cas system (casCE), and other systems, were identified as essential for 14T to survive under acid stress. The results demonstrated that the growth curve and survival ability of $\triangle c p x A$ and $\triangle c p x R$ were decreased under acid stress, and the adhesion and invasion abilities to the mouse colon cancer epithelial cells (MC38) of $\triangle c p x R$ were also decreased compared with the wild type strain, suggesting that the TCS CPxAR plays an essential role in the acid resistance and virulence of $S$. Derby. Also, CasC and CasE were found to be responsible for acid resistance in $S$. Derby. Our results indicate that acid stress induces multiple genes' expression to mediate the acid resistance of $S$. Derby and enhance its pathogenesis during an infection.

Keywords: Salmonella Derby; Tn-seq; acid resistance; CpxAR; CasC/CasE

\section{Introduction}

Salmonella Derby is one of the most prevalent Salmonella serotypes worldwide, and can be isolated from pigs, poultry, and humans, particularly children and the elderly [1-3]. In Europe, $S$. Derby is the 5th most frequently identified serotypes in humans [4]. In France, the $S$. Derby strains isolated from pork and poultry were spread across four different genetic lineages corresponding to four multi-locus sequence types (MLST): ST39, ST40, ST71, and ST682 [5]. The $S$. Derby strains isolated from pork samples were mainly affiliated with ST40, and the ST40 strains was responsible for $94 \%$ of human infections [2]. In China, $S$. Derby was also identified as one of the common serotypes in pigs and humans, with the strains divided into two MLSTs: ST71 and ST40 [6]. Molecular epidemiology analysis showed that $S$. Derby could be transferred along the pork production chain, and further potentially transferred to humans [6]. The Salmonella pathogenicity island (SPI) -1 , $-2,-3,-4$, and -5 regions were detected in the $S$. Derby isolates, suggesting the potential pathogenicity of $S$. Derby [5]. The majority of the $S$. Derby ST40 isolates contained all SPI-23 genes, which have been reported as the critical virulence factor for adhesion and invasion of Salmonella $[7,8]$. 
Salmonella infection is mainly caused by consuming contaminated water or food. Salmonella needs to overcome various stress conditions during infection, such as low $\mathrm{pH}$, high osmotic pressure, low oxygen concentrations, and antimicrobial peptides [9]. Furthermore, previous studies have shown that the intragastric environment's low $\mathrm{pH}$ plays an essential role in resisting Salmonella infection [10-12]. Elderly patients are more likely to suffer infection with Salmonella, which is probably related to reducing in gastric acid secretion after $60[13,14]$. After infecting specific pathogen free (SPF) pigs, $S$. Derby could colonize the tonsils, mesenteric lymph nodes, ileum, and cecum, and the highest level contamination of $S$. Derby was found in the tonsils, cecum, and jejunum [15]. Therefore, $S$. Derby is exposed to the stomach and intestinal acids during infection, and examining the fitness of $S$. derby under the acid stress condition is important for understanding its virulence and pathogenicity.

Salmonella is an intracellular pathogen that can invade the small intestine's epithelium cells and survive in an acidified macrophage vacuole with an external $\mathrm{pH}$ of 4-5 [16-18]. Salmonella has evolved a variety of mechanisms to adapt to a low $\mathrm{pH}$ environment. Several genes are responsible for tolerating the low $\mathrm{pH}$ environment, such as the two-component system (TCS), sigma factors, and those coding for outer membrane proteins. The twocomponent system PhoP/Q, EnvZ/OmpR could sense the $\mathrm{pH}$ and regulate the downstream genes promoting resistance to acid stress [19-21]. The alternative sigma factor RpoE could be activated by the acid stress, which is vital for Salmonella Typhimurium survival in SCV [22]. The expression and translation of rpoS is increased under the acid shock [23]. The inducible lysine decarboxylase and arginine decarboxylase systems play an essential role in the maintaining of intracellular $\mathrm{pH}$ in Salmonella [24]. Furthermore, the transport protein KdpA, the nitrate reductase subunit NarZ, and the genes involved in $\mathrm{NAD}^{+} / \mathrm{NADH}$ metabolism were significantly upregulated under acid stress $[25,26]$. Also, the acidic conditions could be a signal to induce the expression of virulence genes, and help Salmonella's intercellular survival [27]. However, our understanding of how S. Derby resists acidic stresses to infect the host remains elusive.

Our laboratory has collected more than $400 \mathrm{~S}$. Derby isolates from the pork production chain and humans. These strains were divided into ST40 and ST71 by the MLST typing approach [6]. More than 80 strains were then selected to determine the virulence of the S. Derby, and 14T-T8N3 (14T-herein), a strain affiliated with ST40, the most prevalent ST type as revealed by our previous epidemiological investigation [6], exhibited the highest virulence. Here, we determined $S$. Derby $14 \mathrm{~T}^{\prime}$ 's growth ability under different $\mathrm{pH}$ conditions, and demonstrated that $\mathrm{pH} 4$, similar to the acidic environment in the pig stomach after eating [28-30], delayed the growth rate but not the maximum biomass of $S$. Derby $14 \mathrm{~T}$. We then generated a high-quality genome assembly of $14 \mathrm{~T}$ using a de novo long- and short-reads hybrid assembly approach, and used this to identify the essential acid stress genes of $S$. Derby $14 T$ by Tn-seq.

\section{Materials and Methods}

\subsection{Bacterial Strains, Plasmids, and Cell Lines}

The strains and plasmids used in this study are listed in Table 1. Salmonella Derby 14T-T8N3 (14T) was isolated from pork sample in 2014, and stored in Luria-Bertani (LB) broth with $25 \%$ glycerol at $-70{ }^{\circ} \mathrm{C}$ by Jiangsu Key Laboratory of Zoonosis. The $S$. Derby T14 wild type strain (WT) and mutant strains were activated by streaking onto LB plates and were cultured at $37^{\circ} \mathrm{C}$ for $24 \mathrm{~h}$.

The MC38 (Mouse colon cancer epithelial cell) cell line was purchased from Hunan Fenghui Biotechnology Co., Ltd. (Hunan, China). (catalog no. CL0203). Mouse colon cancer epithelial cells (MC 38) were grown in Dulbecco's Modified Eagle Medium (DMEM) (Gibco, Grand Island, NY, USA) with 10\% fetal bovine serum (FBS) (Gibco, Grand Island, NY, USA) and $1 \%$ Penicillin streptomycin at $37^{\circ} \mathrm{C}$ with $5 \% \mathrm{CO}_{2}$. 
Table 1. Bacterial strains and plasmids used in this study.

\begin{tabular}{|c|c|c|}
\hline Strain or Plasmid & Relevant Characteristics & Reference \\
\hline \multicolumn{3}{|l|}{ Escherichia coli } \\
\hline WM3064 & conjugal donor & [31] \\
\hline SM10 גpir & $\begin{array}{l}\text { Host for } \pi \text { requiring plasmids, } \\
\text { conjugal donor }\end{array}$ & {$[32]$} \\
\hline \multicolumn{3}{|l|}{ S. Derby } \\
\hline S. Derby $14 \mathrm{~T}$ & $\begin{array}{l}\text { Isolated from pork sample. } \\
\text { Tcr }\end{array}$ & Laboratory collection \\
\hline$\Delta c p x A$ & $\begin{array}{c}\text { 14T-T8N3, in-frame deletion } \\
\text { in } c p x A, \text { Tcr }\end{array}$ & This study \\
\hline$\Delta c p x R$ & $\begin{array}{c}\text { 14T-T8N3, in-frame deletion } \\
\text { in } c p x R, \mathrm{Tcr}\end{array}$ & This study \\
\hline$\Delta c l c A$ & $\begin{array}{l}\text { 14T-T8N3, in-frame deletion } \\
\text { in } c l c A, T c r\end{array}$ & This study \\
\hline$\Delta c a s C$ & $\begin{array}{l}\text { 14T-T8N3, in-frame deletion } \\
\text { in cas } C, \text { Tcr }\end{array}$ & This study \\
\hline$\Delta c a s E$ & $\begin{array}{l}\text { 14T-T8N3, in-frame deletion } \\
\text { in casE, Tcr }\end{array}$ & This study \\
\hline \multicolumn{3}{|l|}{ Plasmids } \\
\hline pKWM2 & $\begin{array}{c}\text { Tn5 transposon vector library, } \\
\text { OriT, R6K, Kanr }\end{array}$ & [31] \\
\hline pDM4 & $\begin{array}{l}\text { Suicide vector, pir dependent, } \\
\text { R6K, SacBR, Cmr }\end{array}$ & [33] \\
\hline
\end{tabular}

\subsection{Genome Sequencing, Assembly and Annotation of the S. Derby $14 T$}

The $S$. Derby $14 \mathrm{~T}$ genome was sequenced on a PacBio Sequel system and an Illumina Hiseq 4000 platform, and 253,977 long reads (total length $2.06 \mathrm{~Gb}$, N50 $9173 \mathrm{bp}$, max length $45,829 \mathrm{bp}$ ) and $11,020,605 \times 2150 \mathrm{bp}$ paired-end short reads were generated by the PacBio and Illumina sequencing, respectively. The short- and long- reads were fed to Unicycler hybrid assembler v0.4.7 for de novo assembly [34]. The genome was annotated using PROKKA v1.14.5 [35]. The COG annotation was assigned to the genes using eggNOG [36]. The genome was visualized using the CGView server (http:/ / stothard.afns.ualberta.ca/ cgview_server/, accessed on 10 January 2021) [37].

\subsection{Transposon Insertion Library Construction}

A Tn5 transposon plasmid pKWM2, which contains a gene for resistance to kanamycin, was used to construct the transposon mutant library. The donor strain E. coli WM3064 which was used to deliver pKWM2 in this study is an auxotrophic strain whose growth relies on the supplementation of diaminopimelic acid (DAP) in the medium [31]. The $S$. Derby $14 \mathrm{~T}$ and pKWM2-carrying E. coli WM3064 were cultured in LB and LB supplemented with $300 \mu \mathrm{M}$ diaminopimelic acid (DAP) for $12 \mathrm{~h}$, respectively, and then diluted into new corresponding media and cultured to $\mathrm{OD}_{600}$ of $0.4-0.6$. The mixtures of $S$. Derby and WM3064 were spotted into $0.22 \mu \mathrm{m}$ hydrophilic membranes overlaid on LB Agar plates supplemented with $300 \mu \mathrm{M}$ DAP, and cultured at $37^{\circ} \mathrm{C}$ for $12 \mathrm{~h}$. The bacteria in the mixtures were washed by the PBS from the hydrophilic membranes and coating into the LB plates with $50 \mu \mathrm{g} / \mathrm{mL}$ kanamycin and $12.5 \mu \mathrm{g} / \mathrm{mL}$ tetracycline. S. Derby $14 \mathrm{~T}$ was resistant to tetracycline. Therefore, with the presence of tetracycline and absence of DAP in the medium, E. coli WM3064 did not grow. After culturing for $12 \mathrm{~h}$, all of the colonies were collected and stored in LB broth with $25 \%(v / v)$ glycerol at $-70{ }^{\circ} \mathrm{C}$.

\subsection{Library Construction, Sequencing and Bioinformatics Analysis}

The transposon insertion library was cultured in LB medium with $\mathrm{pH} 7.0$ at $37^{\circ} \mathrm{C}$ for $12 \mathrm{~h}$, and then diluted into the new LB medium at $\mathrm{pH} 7.0$ or $\mathrm{pH} 4.0$, respectively. After culturing for $12 \mathrm{~h}$, bacteria were collected, and the genomic DNA was extracted by the TIANamp Bacteria DNA kit (Tiangen, Beijing, China). The library construction and 
sequencing were conducted as previously described [38]. The data were analyzed using TRANSIT ver. 3.1.0 [39]. Briefly, the raw Tn-seq reads were processed using the TPP tool implemented in TRANSIT with parameter protocol Tn5, and the PROKKA annotated 14T genome was used as the reference. The genes with a differential abundance of insertions (Benjamini-Hochberg adjusted $p$-value $<0.05$ ) were identified using the resembling method implemented in TRANSIT with parameter-a used. The essential genes were determined using the Tn5Gaps method with default parameters.

\subsection{Construction of Gene Deletion Mutant Strains}

The deletion mutant strains were constructed via the double exchange of homologous recombination, as previously described [40]. The primers used for the construction of deletion mutant strains are listed in Table 2. The upstream and downstream DNA fragments were amplified using PCR, and inserted into the suicide plasmid pDM4 digested with Sac I and Sal I by a ClonExpress Multis one-step cloning kit (Vazyme, Nanjing, China). The recombined plasmids were transferred into E. coli SM10 $\lambda$ pir and conjugated into the WT to select the single-cross strains at the LB plates with $12.5 \mu \mathrm{g} / \mathrm{mL}$ tetracycline and $40 \mu \mathrm{g} / \mathrm{mL}$ chloramphenicol. Then the double-cross strains were selected at LB plated with $15 \%$ sucrose, and verified by PCR and sequencing.

\subsection{Quantitative Real Time PCR}

S. Derby $14 \mathrm{~T}$ was cultured at $\mathrm{pH} 7.0$ or $\mathrm{pH} 4.0$ at $37^{\circ} \mathrm{C}$ for $6 \mathrm{~h}$, and the total RNA was purified by RNeasy Plus Mini Kits (QIAGEN, USA) following the manufacturer's instructions. NanoDrop determined the quality of total RNA. The genomic DNA was removed using DNase I (Invitrogen, Carlsbad, CA, USA) and cDNA was synthesized using a PrimeScript RT reagent Kit (TaKaRa Biotechnology Co. Ltd., Dalian, China). The primers used for qRT-PCR were listed in Table 2. The qRT-PCR reactions were performed with $10 \mu \mathrm{L}$ Fsu SYBR Green Marter Rox (Roche, Basel, Switzerland), $2 \mu \mathrm{L}$ cDNA, $0.6 \mu \mathrm{L}$ for forward and reverse primers (Table 2), and $6.8 \mu \mathrm{L}$ RNase free water. The mix reactions were measured with the Applied Biosystems 7500 real-time system (Applied Biosystems, Foster City, CA, USA). gyrB was used as a control gene, and the transcription levels of target genes were determined by $2^{-\Delta \Delta C t}$.

\subsection{The Growth Characteristics of WT and Deletion Mutant Strains}

The $S$. Derby $14 \mathrm{~T}$ and deletion mutant strains were cultured at $37^{\circ} \mathrm{C}$ for $16 \mathrm{~h}$. The cultures were diluted into conical flasks containing $20 \mathrm{~mL} \mathrm{LB}$ broth medium with different $\mathrm{pHs}\left(\mathrm{pH} 2.0, \mathrm{pH} 4.0, \mathrm{pH} 5.5\right.$, or $\mathrm{pH} 7.0$ ), and then incubated at $37^{\circ} \mathrm{C}$ with $180 \mathrm{rpm} / \mathrm{min}$. At the indicated time points, the cell densities of each strain were measured at $600 \mathrm{~nm}$. The initial cell density of these strains was adjusted to an $\mathrm{OD}_{600}$ of 0.05 , and the $\mathrm{pH}$ of each medium was adjusted with $3 \mathrm{M} \mathrm{HCl}$.

\subsection{Survival Analysis}

The cultures of $S$. Derby $14 \mathrm{~T}$ and deletion mutant strains were diluted into the new $\mathrm{LB}$ medium, and then incubated until they reached an $\mathrm{OD}_{600}$ of $1.0 .1 \mathrm{~mL}$ of each culture was resuspended in $\mathrm{LB}$ medium at $\mathrm{pH} 7.0$ or $\mathrm{pH} 4.0$, and then static cultured at $37^{\circ} \mathrm{C}$. At the indicated time points, an aliquot of each culture was removed and serially diluted with PBS, and then plated onto the LB plates to determine the survival rate. 
Table 2. Primers used in this study.

\begin{tabular}{|c|c|c|}
\hline Primer Name & Primer Sequence $\left(5^{\prime}\right.$ to $\left.3^{\prime}\right)$ & Target \\
\hline cpxA-up-F & GAGCGGATAACAATTTGTGGAATCCCGGGAAACATTTAAGTCAGGAAGTGCTGGG & For $c p x A$ deletion mutant \\
\hline cpxA-up-R & TTCGACAATCGGATCGTTCGCAAGTTCAGCTTCTA & For $\operatorname{cp} x A$ deletion mutant \\
\hline cpxA-down-F & CGAACGATCCGATTGTCGAAAGCGCCATGCAGCAG & For $c p x A$ deletion mutant \\
\hline cpxA-down-R & AGCGGAGTGTATATCAAGCTTATCGATACCATCTCTTGAGGAGCTTTGGGAGCGG & For $c p x A$ deletion mutant \\
\hline cpxA-out-F & GCTCCTCGAAATGGAAGGTTTTAAT & For $c p x A$ deletion mutant \\
\hline cpxA-out-R & GCTCGCTACAAGTGGGTGAAGAAGG & For $c p x A$ deletion mutant \\
\hline cpxR-up-F & GAGCGGATAACAATTTGTGGAATCCCGGGAAAAAAACTGAATGCCAGCGTTGAGG & For $c p x R$ deletion mutant \\
\hline cpxR-up-R & GTTAGAAATATCGATGCTGTCATCCAAAAGCTCAA & For $c p x R$ deletion mutant \\
\hline cpxR-down-R & AGCGGAGTGTATATCAAGCTTATCGATACCCGTCCTTCAGAGGTCACCAGTAATA & For $c p x R$ deletion mutant \\
\hline cpxR-out-F & TAACCAGCCGTCCATAGGTTTGATT & For $c p x R$ deletion mutant \\
\hline cpxR-out-R & CGACATCACCAGCAGGTCATTGATC & For $c p x R$ deletion mutant \\
\hline clcA-up-F & GAGCGGATAACAATTTGTGGAATCCCGGGAATATGCTTTGCCATCGACATCGTAC & For $c l c A$ deletion mutant \\
\hline clcA-up-R & CTGGTAGTTAATTAACCGGCGAATCTGATCTCTGC & For $c l c A$ deletion mutant \\
\hline clcA-down-F & GCCGGTTAATTAACTACCAGCTCATTTTGCCAATG & For $c l c A$ deletion mutant \\
\hline clcA-down-R & AGCGGAGTGTATATCAAGCTTATCGATACCCCTTCGTTAACCTGATCGTCAAAGG & For $c l c A$ deletion mutant \\
\hline clcA-out-F & AGACAGTCTGCGTGGCCGTGGTAGC & For $c l c A$ deletion mutant \\
\hline clcA-out-R & TACGCTTATCGGGCCTGGAACATCT & For $c l c A$ deletion mutant \\
\hline casC-up-R & CATTCATATTCAGGCTCTGAGAGGAGATACGCAGA & For $\operatorname{cas} C$ deletion mutant \\
\hline casC-down-F & TCAGAGCCTGAATATGAATGAGGTCTATGCACAGG & For cas $C$ deletion mutant \\
\hline casC-down-R & AGCGGAGTGTATATCAAGCTTATCGATACCGCACAGCAAAAATTGGTAATGACGA & For cas $C$ deletion mutant \\
\hline casC-out-F & CTGCTTGTCTGAGGGATTTCGCTCC & For cas $C$ deletion mutant \\
\hline casC-out-R & AGCGGCAACGCCAGAGGGTGACTTT & For cas $C$ deletion mutant \\
\hline casE-up-F & GAGCGGATAACAATTTGTGGAATCCCGGGACTTACACGTTGGCGCAGCTTCAGAC & For casE deletion mutant \\
\hline casE-up-R & GCCAGACGTTTGCTGCCGGGAAAGAGATCCCATAA & For casE deletion mutant \\
\hline casE-down-F & CCCGGCAGCAAACGTCTGGCGCAGGGGTACGGTAA & For casE deletion mutant \\
\hline casE-down-R & AGCGGAGTGTATATCAAGCTTATCGATACCAGGAATAGACCCGCACTCCCGCCTC & For casE deletion mutant \\
\hline casE-out-F & GGGATTATCACACGGTGCAGATGCC & For casE deletion mutant \\
\hline casE-out-R & CGGCGATCTCAAATGCTTTGGGCAC & For casE deletion mutant \\
\hline gyrB-q-F & TGATTGCGGTGGTTTCCGTA & qRT-PCR \\
\hline gyrB-q-R & GACGACGATTTTCGCGTCAG & qRT-PCR \\
\hline cpxA-q-F & AAGCTGAACTTGCGAACGAT & qRT-PCR \\
\hline cpxA-q-R & CATCTCTACGCGGCCATATT & qRT-PCR \\
\hline cpxR-q-F & TTGATGATGACCGAGAGCTG & qRT-PCR \\
\hline cpxR-q-R & TACCGTTTTTCTTCGGCATC & qRT-PCR \\
\hline
\end{tabular}


Table 2. Cont.

Primer Name

clcA-q-F

clcA-q-R

lysP-q-F

lysP-q-R

phoQ-q-F

phoQ-q-R

phoP-q-F

phoP-q-R

degP-q-F

$\operatorname{deg} \mathrm{P}-\mathrm{q}-\mathrm{R}$

casE-q-F

casE-q-R

mgrB-q-F

mgrB-q-R

crcB-q-F

crcB-q-R

casC-q-F

casC-q-R
Primer Sequence $\left(5^{\prime}\right.$ to $\left.3^{\prime}\right)$

Target

CTCAGCAAATTGTGCGCTTA

CCAGTAACGCCGAAAGGATA

ACAACTGGGCGGTGACTATC

TACGCCAACGATGATGAAGA

CTCGCCAAATGGGAAAATAA

CATTCCGGTTGAATGCTTTT

TGCGCGTACTGGTTGTAGAG

TCATCCGGCAGACCTAAATC

GTATGCCGCGTAATTTCCAG

GAATTTACGCCCATCGCTAA

TTATCGCCGCGAAGAGTTAC

GGCTATCACCCTGCGTTTTA

AATTTCGATGGGTCGTTCTC

CGCAAATACCGCTGAAAAAT

CCCGGTGGATGCTAAGTATG

GGTCGTAATGAGCACTTTCCA

AGAACATCGCCAACTGCTTT

CAGTTCCGCTTCCTCTTCTG
qRT-PCR

qRT-PCR

qRT-PCR

qRT-PCR

qRT-PCR

qRT-PCR

qRT-PCR

qRT-PCR

qRT-PCR

qRT-PCR

qRT-PCR

qRT-PCR

qRT-PCR

qRT-PCR

qRT-PCR

qRT-PCR

qRT-PCR

qRT-PCR 


\subsection{Adhesion and Invasion Assay of MC 38 Cells}

The $S$. Derby $14 \mathrm{~T}$ WT, $\Delta c p x A$, and $\triangle c p x R$ were cultured in LB medium at $37^{\circ} \mathrm{C}$ for $16 \mathrm{~h}$, the cultures diluted into the new LB medium and incubated to an $\mathrm{OD}_{600}$ of 1.0. The MC38 cells were seeded into 24 well plates with $4 \times 10^{5}$ cells per well, and overnight cultured at $37^{\circ} \mathrm{C}$ with $5 \% \mathrm{CO}_{2}$. A total of $1 \mathrm{~mL}$ of bacteria was collected and washed twice with DMEM, and then added to each well with a MOI of 20:1. The cells were incubated at $37^{\circ} \mathrm{C}$ for $1 \mathrm{~h}$. For adhesion, the cultured cells were washed twice with DPBS (Gibco, Grand Island, NY, USA), and lysed with $0.1 \%$ Triton X-100. The lysates were serially diluted and the appropriate dilutions were coated on the LB plates to calculate the number of bacteria. For invasion, the cultured cells were washed twice with DPBS, while $100 \mu \mathrm{g} / \mathrm{mL}$ gentamycin was added to kill the extracellular bacteria, and cultured at $37{ }^{\circ} \mathrm{C}$ with $5 \% \mathrm{CO}_{2}$. After further incubation for $1 \mathrm{~h}$, the $0.1 \%$ Triton $\mathrm{X}-100$ was used to lyse the cells, and the number of bacteria was calculated.

\subsection{Data Availability}

The genome sequence and Tn-seq data were deposited in the CNGB database under the Bioproject accession no CNP0001625.

\section{Results}

\subsection{Overview of the S. Derby $14 T$ Genome}

The genome sequence of strain $14 \mathrm{~T}$ was determined using a short- and long- readsbased hybrid de novo assembly approach, and an assembly composed of 11 scaffolds was generated, with a total length of 4,914,080 bp (Figure 1A and Table 3). The two longest scaffolds were 4,073,894 bp and 805,643 bp long, respectively, accounting for $99.3 \%$ of the assembly's total length. Notably, 4579 protein-coding genes, 22 rRNA, and 84 tRNA coding genes were predicted in the $14 \mathrm{~T}$ genome. The Clusters of Orthologous Genes (COG) annotation was successfully assigned to $95.7 \%$ of these genes (Figure 1B).

Table 3. Features of the $S$. Derby 14 T genome.

\begin{tabular}{cc}
\hline Features & Value \\
\hline Total reading base pairs (bp) & $4,914,080$ \\
Scaffold number & 11 \\
N50 (bp) & $4,073,894$ \\
GC content (\%) & 52.03 \\
tRNAs & 84 \\
rRNAs & 22 \\
Protein-coding sequences & 4579 \\
\hline
\end{tabular}

\subsection{Identification of Genes Involved in Acid Stress Resistance by Tn-seq Analysis}

To evaluate $S$. Derby $14 \mathrm{~T}^{\prime}$ s growth ability under low $\mathrm{pH}$, we characterized the growth curves of WT in the LB medium with $\mathrm{pH}$ 2.0, $\mathrm{pH} 4.0, \mathrm{pH} 5.5$, and $\mathrm{pH}$ 7.0. The results demonstrated that the WT strain could not survive at $\mathrm{pH} 2.0$, and the growth curve of WT cultured at $\mathrm{pH} 5.5$ exhibited no significant difference compared to that at $\mathrm{pH}$ 7.0. However, the WT cultured in $\mathrm{pH} 4.0$ exhibited a significantly delayed growth rate, but reached a similar maximum biomass to the $\mathrm{pH} 7.0$ condition (Figure 2A). Interestingly, $\mathrm{pH} 4.0$ represents the actual stomach acidity of pigs after eating [28-30]. Therefore, we constructed a high-throughput Tn5-based mutant library of $S$. Derby 14T, and determined the genes involved in acid stress resistance by Tn-seq analysis to identify the genes responsible for acid resistance $(\mathrm{pH} 4.0)$. 


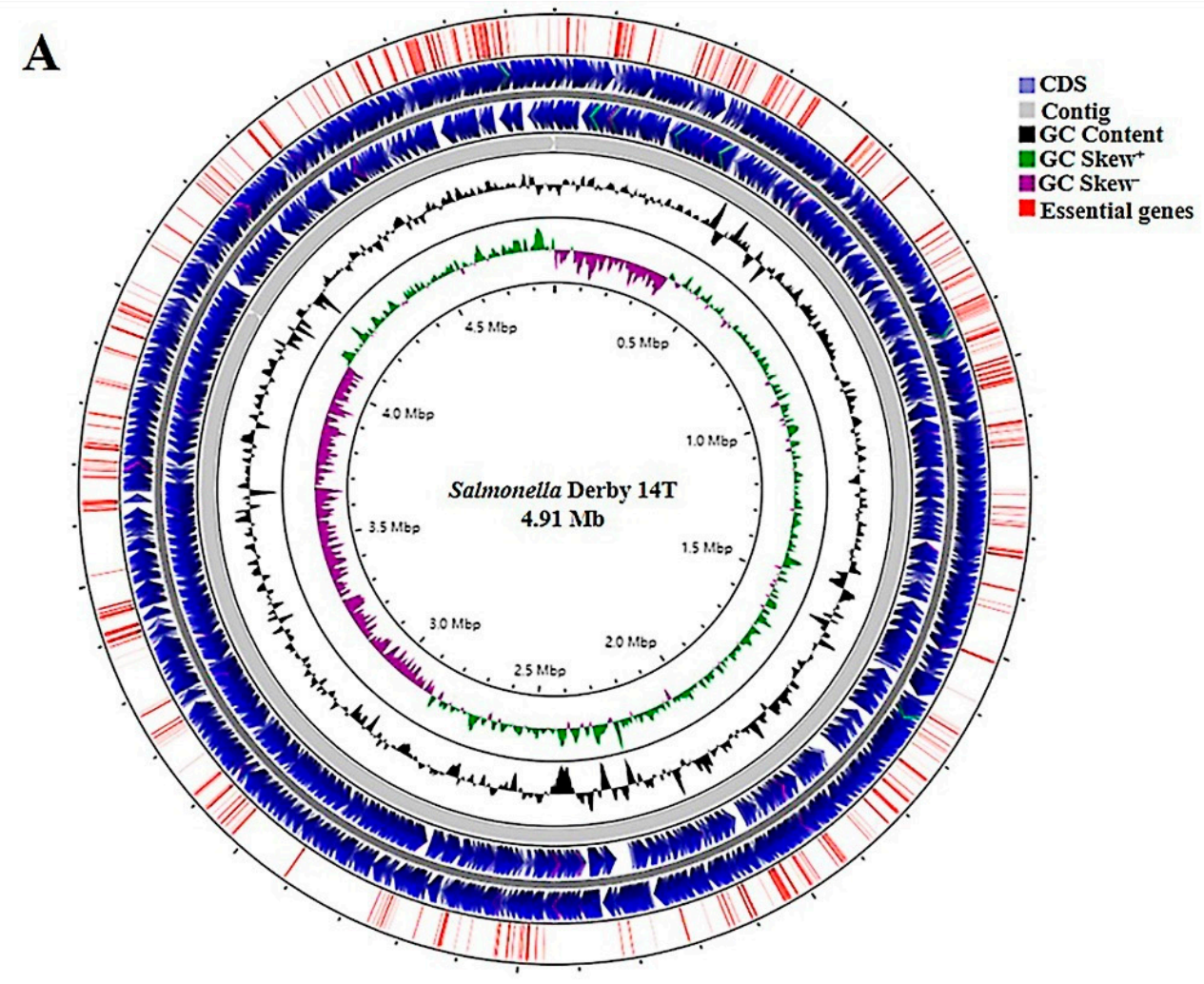

B

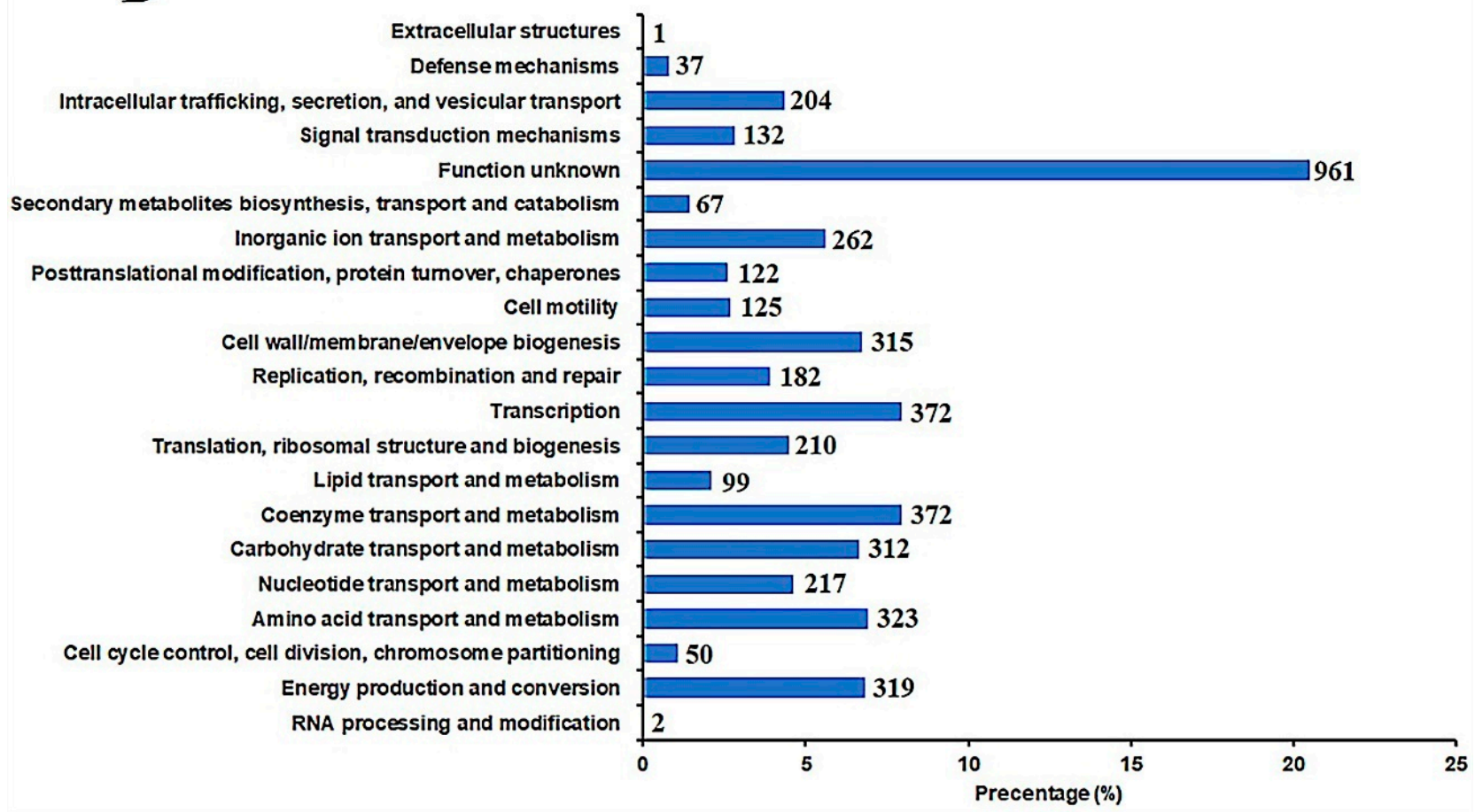

Figure 1. Overview of the Salmonella Derby $14 \mathrm{~T}$ genome. (A) Circular representation of the S. Derby 14T genome. The contents of the feature rings (starting with the innermost ring) are as follows: GC skew, GC content, CDS on the two strands, and the distribution of 581 conditional essential genes. (B) COG annotation of genes in the genome of S. Derby $14 \mathrm{~T}$. The $\mathrm{y}$-coordinate denotes the COG terms, and the $\mathrm{x}$-coordinate is the percentage of genes affiliated with the term in the total annotated genes. 


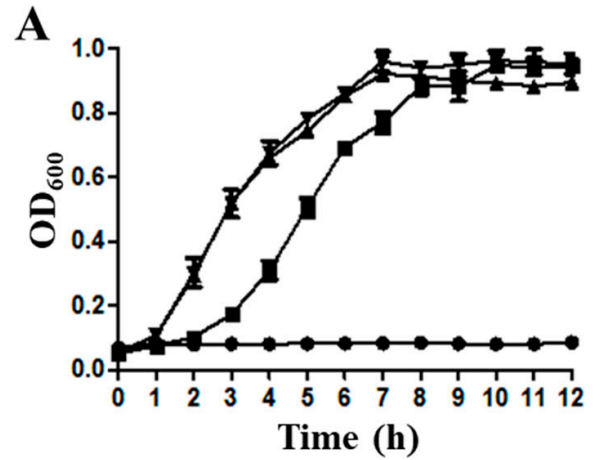

C

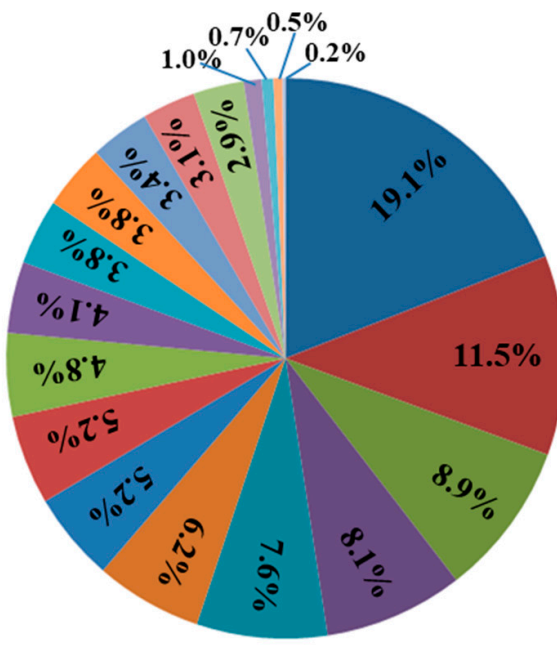

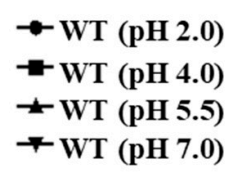

B

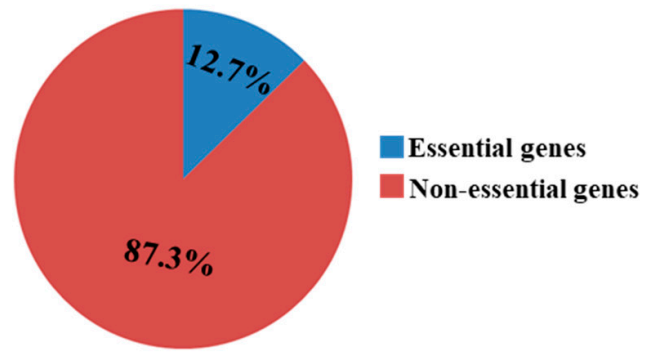

- Translation, ribosomal structure and biogenesis

- Nucleotide transport and metabolism

Energy production and conversion

- Cell wall/membrane/envelope biogenesis

- Function unknown

- Replication, recombination and repair

n Coenzyme transport and metabolism

- Transcription

- Lipid transport and metabolism

- Amino acid transport and metabolism

- Carbohydrate transport and metabolism

Inorganic ion transport and metabolism

- Intracellular trafficking, secretion, and vesicular transport

- Cell cycle control, cell division, chromosome partitioning

- Posttranslational modification, protein turnover, chaperones

- Signal transduction mechanisms

- Defense mechanisms

Secondary metabolites biosynthesis, transport and catabolism

nNA processing and modification

\section{D}

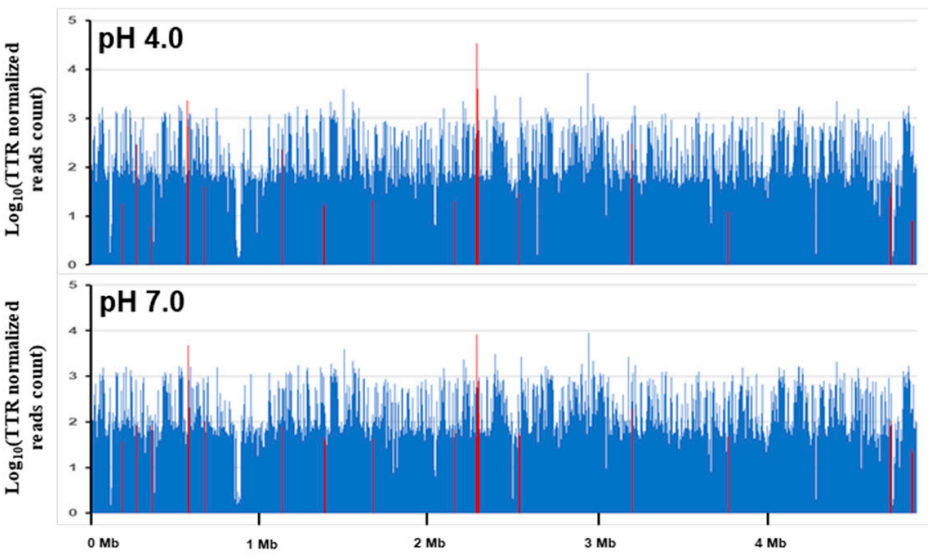

Figure 2. Tn-seq analysis to identify genes involved in acid resistance. (A) The growth curves of $S$. Derby $14 \mathrm{~T}$ at different $\mathrm{pH}$ conditions. The WT was grown in LB medium at $\mathrm{pH}$ 2.0, 4.0, 5.5 and 7.0, and the $\mathrm{OD}_{600}$ values were determined at the indicated time points. The experiments were repeated three times. (B) The pie chart of essential genes and non-essential genes as revealed by Tn-seq. (C) Functional analysis of essential genes in LB medium at pH 7.0. (D) Distribution of the numbers of insertions in the CDS regions across the 14T genome. The upper panel showing the average insertion numbers for each gene of the three replications grown under the $\mathrm{pH} 7.0$ conditions, while the lower panel was those for $\mathrm{pH} 4.0$ acidic conditions. The insertion numbers were shown as Log10 (TTR normalized reads count). Red lines indicate the genes with significantly different insertions, as revealed by the Tn-seq analysis (BH adjusted $p$-value $<0.05)$. 
The mutant library was first grown at pH 7.0 in LB medium, and then challenged at $\mathrm{pH}$ 4.0. After culturing for $12 \mathrm{~h}$, the genomic DNA of $S$. derby $14 \mathrm{~T}$ under $\mathrm{pH} 7.0$ and $\mathrm{pH} 4.0$ conditions were extracted, and the sequencing libraries were constructed. In total, $26,988,364$ single-end valid reads (i.e., reads with valid Tn prefix, and insert size $>20 \mathrm{bp}$ ) (on average 4,498,060 reads per sample, $n=6$ ) were generated from the six Tn-seq libraries, and $23,672,555$ reads $(87.7 \%$ of the total reads) were successfully mapped back to the $14 \mathrm{~T}$ genome as revealed by the TPP tool. Based on the Tn-seq data generated from the three samples grown at $\mathrm{pH} 7.0,581$ essential genes were identified using the Tn5Gaps method implemented in the TRANSIT tool, and accounted for $12.7 \%$ of all 4579 genes (Figure 2B). The majority of the essential genes were mainly enriched in the core cellular metabolic pathways, including translation, ribosomal structure and biogenesis $(19.1 \%)$, nucleotide transport and metabolism (11.5\%), energy production and conversion $(8.9 \%)$, and cell wall/membrane/envelope biogenesis (8.1\%) (Figures 1A and 2C).

Overall, 35 genes were identified as the acid essential genes, including 17 genes with a diminished abundance of insertions in the $\mathrm{pH} 4.0$ condition, and 18 genes with a greater abundance of insertions (Table 4). These genes were located across the genome (Figure 2D). As expected, many acid-stress-associated genes were identified by Tn-seq, such as the two-component system $\mathrm{CpxA}$ and $\mathrm{PhoP} / \mathrm{PhoQ}$, which have been identified as responsible for acid resistance in E. coli and Salmonella Typhimurium, respectively [41-43]. RseB, lysP, and $\operatorname{deg} P$ also showed significantly lower insertions in the $\mathrm{pH} 4.0$ condition than at $\mathrm{pH} 7.0$, which have been identified as being involved in the regulated intramembrane proteolysis (RIP) responsible for the environmental stress [44]. Furthermore, the CRISPR system cascade subunits cas $C$ and $c a s E$, the transporter encoding genes $k u p, \operatorname{crc} B$, and $c l c A$, also showed a diminished abundance of insertions in the $\mathrm{pH} 4.0$ condition. Taken together, these results demonstrated that these genes could be involved in the acid resistance in S. Derby $14 \mathrm{~T}$.

Table 4. Genes showing significantly different insertions under the acid condition identified by Tn-seq.

\begin{tabular}{ccc}
\hline Gene & Description & log2FC \\
\hline T141_00187 & Sensor histidine kinase, CpxA & -1.08 \\
T141_02433 & Virulence transcriptional regulatory & -1.07 \\
protein, PhoP & -0.99 \\
T141_02432 & Virulence sensor histidine kinase, PhoQ & -1.72 \\
T141_03065 & PhoP/PhoQ regulator, MgrB & -1.01 \\
T141_01611 & Sigma-E factor regulatory protein, RseB & -1.73 \\
T141_02070 & Lysine-specific permease, LysP & -0.86 \\
T142_00594 & Periplasmic serine endoprotease, DegP & -1.41 \\
T141_01333 & CRISPR system Cascade subunit, CasC & -1.65 \\
T141_01335 & CRISPR system Cascade subunit, CasE & -3.8 \\
T141_00366 & Low affinity potassium transport system & -2.03 \\
T141_03609 & protein, kup & -1.7 \\
T142_00588 & Putative fluoride ion transporter, CrcB & -1.67 \\
T142_00709 & H(+)/Cl(-) exchange transporter, ClcA & -1.42 \\
T141_00659 & Glutamate 5-kinase, ProB & -1.38 \\
T142_00710 & Endoglucanase, BcsZ & -1.15 \\
T141_01331 & $\gamma$-glutamyl phosphate reductase, ProA & -1.06 \\
T141_00565 & hypothetical protein & 1.09 \\
T141_02199 & hypothetical protein & 1.74 \\
T141_02191 & D-inositol-3-phosphate glycosyltransferase, \\
& MshA & \\
\hline & dTDP-4-dehydrorhamnose & 3\%2C5-epimerase, RfbC \\
\hline
\end{tabular}


Table 4. Cont.

\begin{tabular}{|c|c|c|}
\hline Gene & Description & $\log 2 \mathrm{FC}$ \\
\hline T141_02189 & dTDP-4-dehydrorhamnose reductase, RfbD & 1.98 \\
\hline T141_02193 & $\begin{array}{l}\text { Glucose-1-phosphate cytidylyltransferase, } \\
\text { RfbF }\end{array}$ & 2.29 \\
\hline T141_02194 & CDP-glucose 4\%2C6-dehydratase, RfbG & 2.02 \\
\hline T141_02196 & CDP-abequose synthase, $\mathrm{RfbJ}$ & 2.64 \\
\hline T141_02201 & $\begin{array}{l}\text { Mannose-1-phosphate guanylyltransferase, } \\
\text { RfbM }\end{array}$ & 1.23 \\
\hline T141_02198 & Abequosyltransferase, $\mathrm{RfbV}$ & 2.37 \\
\hline T141_01096 & Cell division protein, FtsP & 1.54 \\
\hline T141_00272 & $\begin{array}{l}\text { Sec-independent protein translocase } \\
\text { protein, TatC }\end{array}$ & 1.81 \\
\hline T141_02202 & $\begin{array}{l}\text { Phosphoglucosamine mutase, GlmM } \\
\text { CDP-6-deoxy-L-threo-D-glycero-4- }\end{array}$ & 1.9 \\
\hline T141_02192 & $\begin{array}{c}\text { hexulose-3-dehydrase reductase, } \\
\text { AscD }\end{array}$ & 2.05 \\
\hline T141_00569 & $\begin{array}{l}\text { D-inositol-3-phosphate glycosyltransferase, } \\
\text { MshA }\end{array}$ & 2.09 \\
\hline T141_02195 & $\begin{array}{c}\text { dTDP-4-dehydro-2\%2C6-dideoxy-D- } \\
\text { glucose 3-dehydratase, } \\
\text { SpnO }\end{array}$ & 2.12 \\
\hline T141_03062 & Peptidoglycan D\%2CD-transpeptidase, FtsI & 2.41 \\
\hline T141_02203 & hypothetical protein & 1.58 \\
\hline T141_00570 & hypothetical protein & 1.7 \\
\hline T141_02200 & hypothetical protein & 1.83 \\
\hline
\end{tabular}

\subsection{Validation of the Tn-seq Identified Genes with qRT-PCR}

Ten genes identified by the Tn-seq analysis were selected for verification by qRT-PCR. The qRT-PCR results showed that the transcription level of $c l c A$ was highly up-regulated after stimulation by acidic conditions (Figure 3). Furthermore, the expression levels of cas $C$, casE, and $m g r B$ also increased under the $\mathrm{pH} 4.0$ condition compared to $\mathrm{pH} 7.0$. The other genes showed no significant differences in expression between the $\mathrm{pH} 4.0$ and $\mathrm{pH} 7.0$ conditions (Figure 3), likely because they were not involved in acid stress at the transcriptional level.

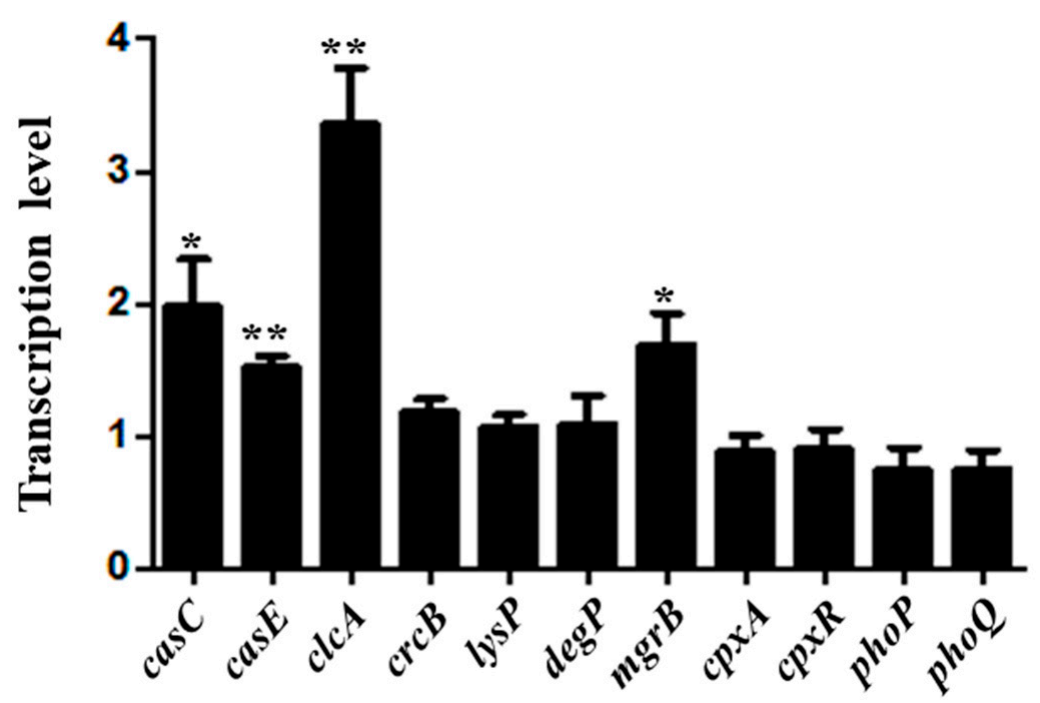

Figure 3. Validation of the genes identified by Tn-seq using qRT-PCR. The WT strain was cultivated at $\mathrm{pH} 7.0$ and $\mathrm{pH} 4.0$, the transcriptional levels of indicated genes show the difference relative to the WT cultured at $\mathrm{pH}$ 7.0. gyrB was used as the standard gene. Error bars were shown as Standard error of means $(\mathrm{SEM})(n=3){ }^{*}, p \leq 0.05 ;{ }^{* *}, p \leq 0.01$ (Student's $t$-test). 


\subsection{ClcA Was Responsible for Acid Stress Resistance}

To further confirm the function of $c l c A$ in the acid resistance of $S$. Derby, the deletion mutant strain of $c l c A$ was constructed, and the growth curve of the mutant under acid stress was determined. The bacterial growth curves of the WT and $\triangle c l c A$ showed no significant difference under the $\mathrm{pH} 7.0$ condition, whereas the growth rate of the $\triangle c l c A$ mutant strain was much lower than that of WT at pH 4.0 (Figure 4). These results indicated that the $c l c A$ plays a vital role in $S$. Derby $14 T^{\prime}$ 's growth under acid stress.

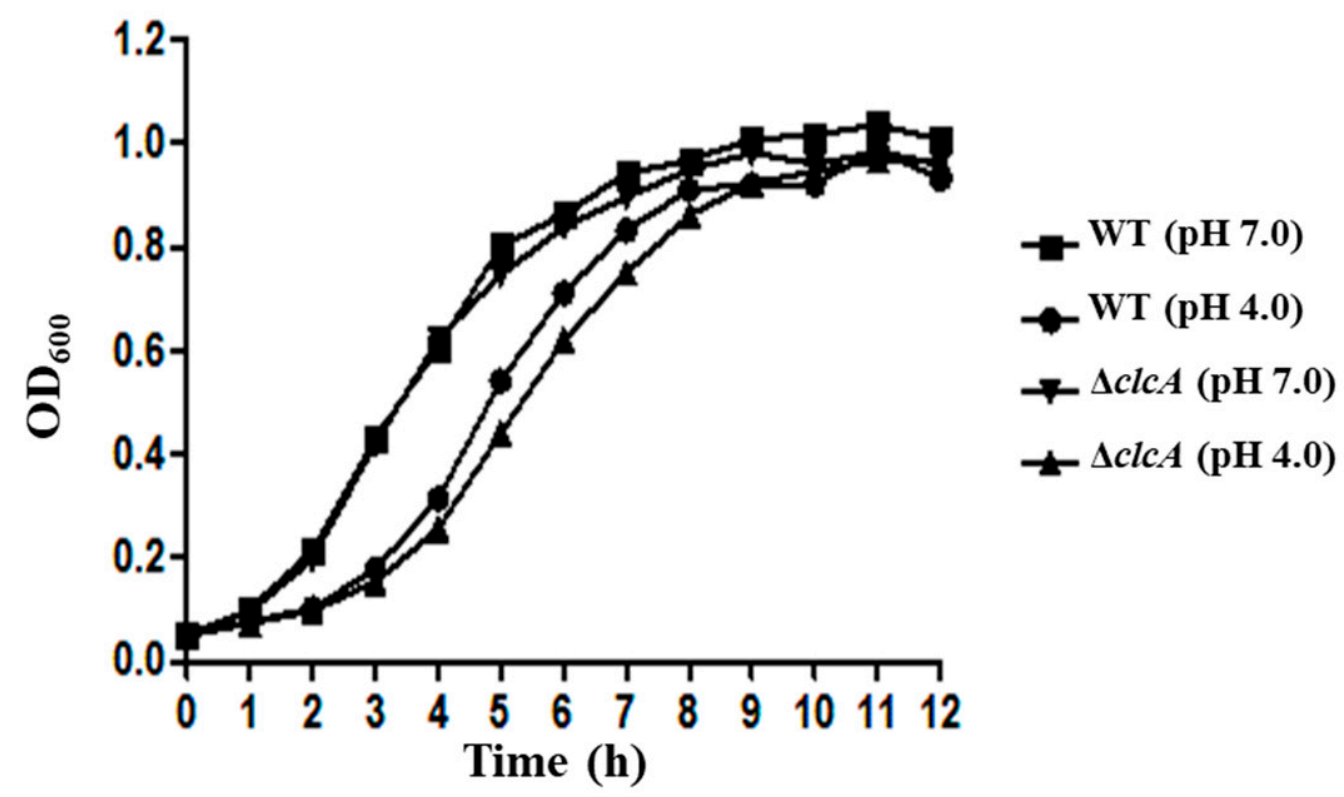

Figure 4. Growth curves of WT and $\triangle c l c A$ in LB medium at $\mathrm{pH} 4.0$ and $\mathrm{pH}$ 7.0. The overnight cultures of WT or $\Delta c l c A$ were diluted to a new LB medium at $\mathrm{pH} 4.0$ and $\mathrm{pH} 7.0$, respectively. Then, the bacteria were cultured at $37^{\circ} \mathrm{C}$ with $180 \mathrm{rpm}$, the $\mathrm{OD}_{600}$ values were detected at the indicated time points. The experiments were repeated three times.

\subsection{CPxAR Was Responsible for the Acid Stress Resistance and Virulence of S. Derby}

CpxAR is the two-component system that has been reported as involved in acid stress tolerance [41]. The growth properties of the WT, $\triangle c p x A$, and $\triangle c p x R$ strains were also investigated in this study. When the strains were grown in LB medium with $\mathrm{pH}$ 7.0 , the growth curves showed no significant difference between the WT and $\triangle c p x A$ or $\triangle c p x R$ mutant strains; however, the $\triangle c p x A$ strain exhibited dramatic growth defect under the stress condition of $\mathrm{pH} 4.0$, while the growth activity of the $\Delta c p x R$ strain was slightly decreased compared with the WT strain at $\mathrm{pH} 4.0$ (Figure 5A). The survival ability of $\triangle c p x A$ and $\Delta c p x R$ strains significantly decreased compared to the WT after treating with $\mathrm{pH} 4.0$ for $1 \mathrm{~h}$, while no difference was observed at $2 \mathrm{~h}$ (Figure $5 \mathrm{~B}$ ). These results demonstrated that $\mathrm{CpxA}$ and $\mathrm{CpxR}$ contribute to the growth ability of $S$. Derby under the stress condition.

To explore the roles of CpxAR in the virulence of $S$. Derby, the $\triangle c p x R$ and $\triangle c p x R$ mutants were inoculated to MC38 cells and the adhesion and invasion abilities were determined. As shown in Figure 5C,D, the adhesion and invasion rates of the $\Delta c p x R$ strain were significantly decreased compared to the WT, while no difference was observed between $\triangle c p x A$ and WT, indicating that CpxR contributes to the virulence of $S$. Derby. 
A

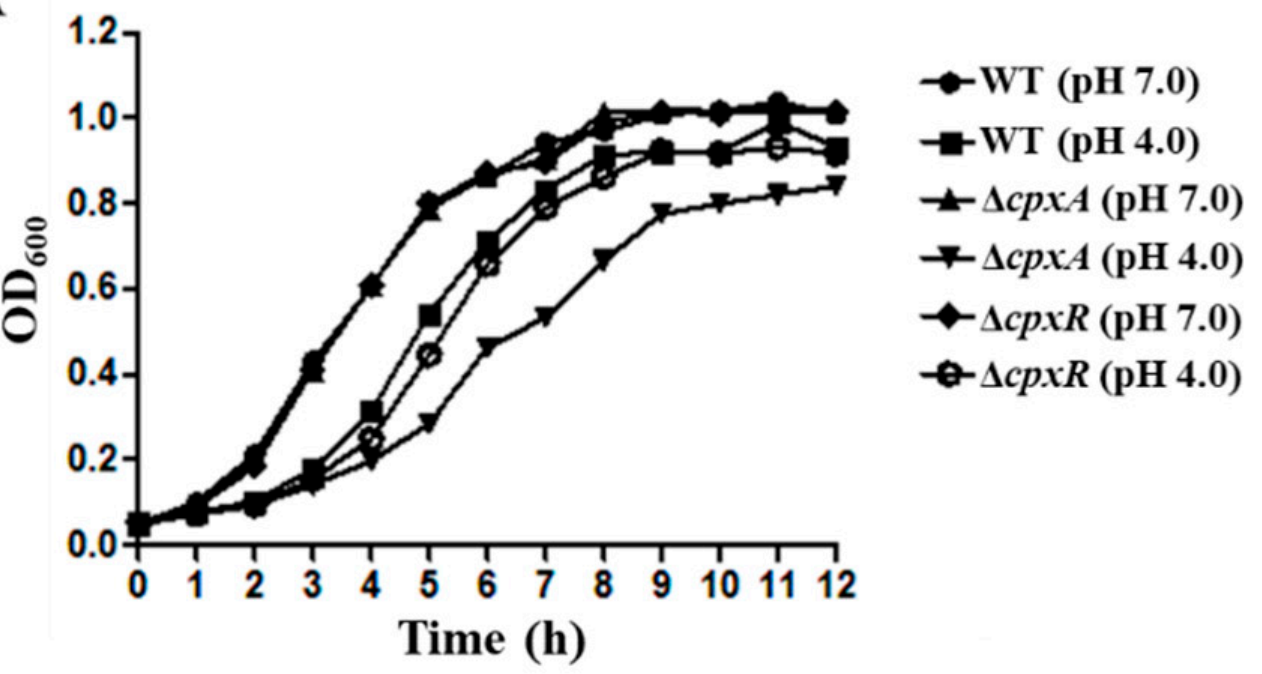

B
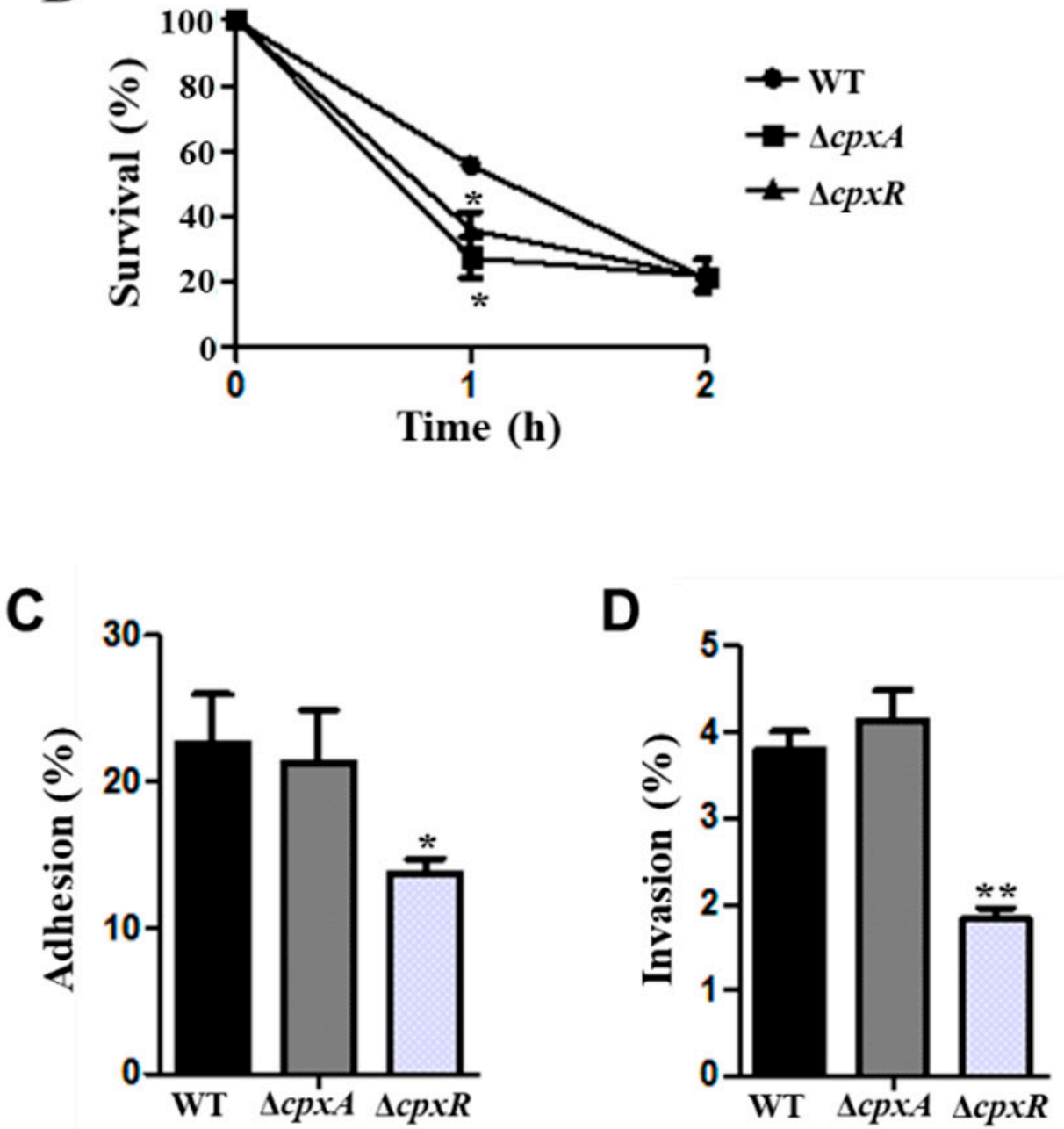

Figure 5. The function of CpxAR in acid resistance and virulence of $S$. Derby. (A) Growth curves of WT, $\triangle c p x A$ and $\triangle c p x R$ in LB mediums at $\mathrm{pH} 4.0$ and $\mathrm{pH} 7.0$. (B) Survival ability of WT, $\Delta c p x A$ and $\triangle c p x R$ at $\mathrm{pH}$ 4.0. Adhesion (C) and invasion (D) rate of WT, $\triangle c p x A$ and $\triangle c p x R$ after infection with the MC38 cells. All the experiments were repeated three times. ${ }^{*}, p \leq 0.05 ;{ }^{* *}, p \leq 0.01$ (Student's $t$-test). 


\subsection{CasC/CasE Were Involved in the Acid Stress Resistance}

We also constructed the deletion mutant strains of $c a s C$ and $c a s E$ genes, and the growth curves of WT, $\triangle c a s C$, and $\triangle c a s E$ strains showed no significant difference under the acid condition (Figure $6 \mathrm{~A}$ ). The survival ability of $\Delta c a s \mathrm{C}$ was $35.3 \%$ and $7.9 \%$ after treated with acid stress ( $\mathrm{pH} 4.0$ ) for $1 \mathrm{~h}$ and $2 \mathrm{~h}$, which was lower than that of WT (Figure 6B). The survival ability of $\triangle$ cas $E$ also decreased compared to the WT after treatment at $\mathrm{pH} 4.0$ for $1 \mathrm{~h}$ and $2 \mathrm{~h}$ (Figure 6B). These results showed that CasC and CasE play an essential role in the survival ability of $S$. Derby.
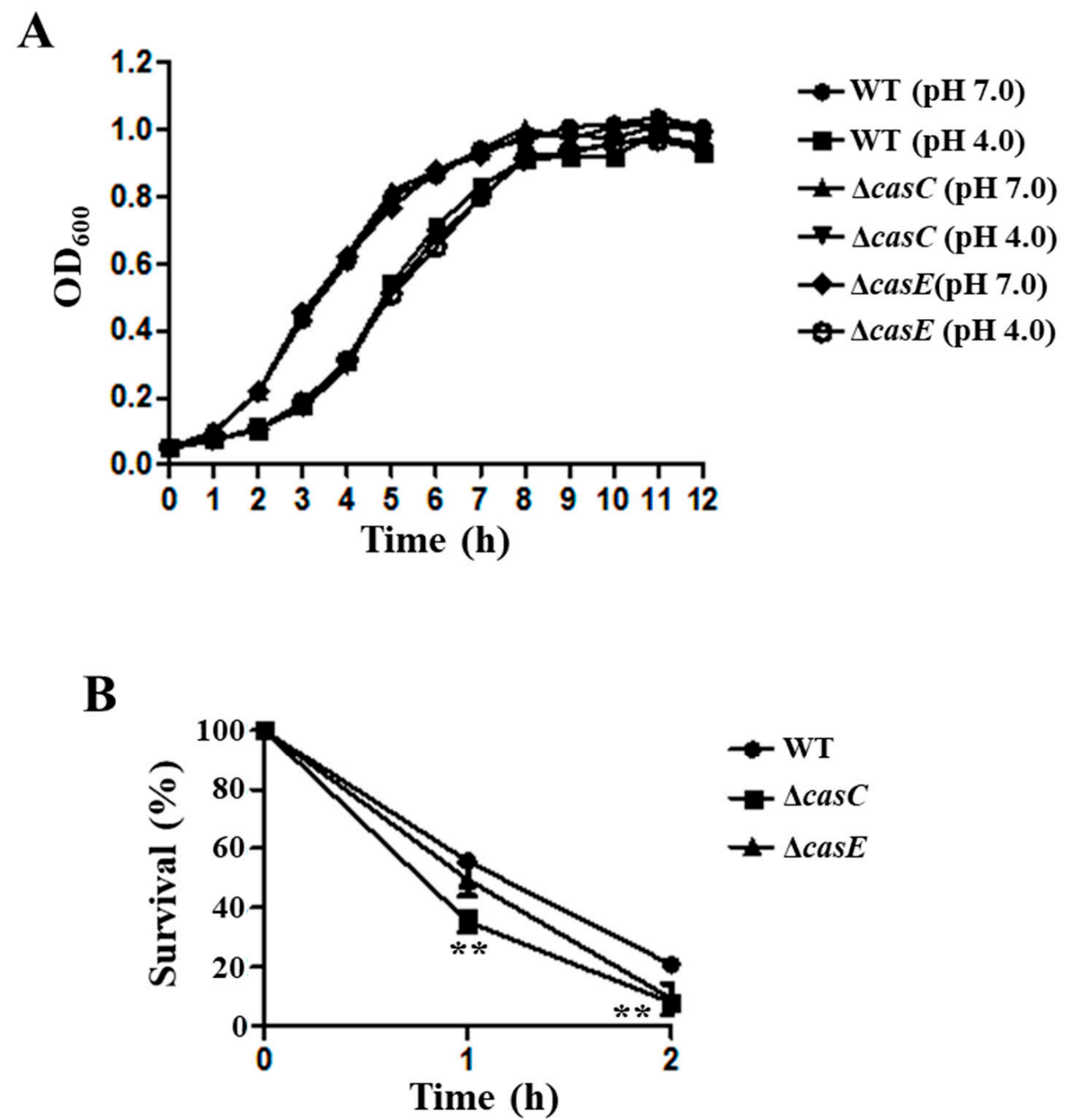

Figure 6. CasC and CasE were involved in the acid resistance of $S$. Derby. (A) Growth curves of WT, $\Delta c a s C$, and $\Delta c a s E$ in LB medium at $\mathrm{pH} 4.0$ and $\mathrm{pH} 7.0$. (B) Survival ability of WT, $\Delta c a s C$, and $\Delta c a s E$ at $\mathrm{pH}$ 4.0. All the experiments were repeated three times. ${ }^{* *}, p \leq 0.01$ (Student's $t$-test).

\section{Discussion}

The stomach's acidic environment can be considered the first barrier against foodborne pathogens, and several organic acids can be produced in the stomach, including lactic, acetic, propionic, and butyric acid [12]. Recent epidemiological studies have demonstrated that $S$. Derby has become one of the most prevalent Salmonella serotypes in pigs and humans [1-3]. As a foodborne pathogen, $S$. Derby also needs to resist acid stress in the stomach during the infection process, before it can colonize the ileum and cecum [15]. We noted that the growth ability of $S$. Derby $14 \mathrm{~T}$ was decreased under the $\mathrm{pH} 4.0$ condition compared to the WT grown in $\mathrm{pH} 7.0$ and $\mathrm{pH} 5.5$ at the log-phase, but was not significantly 
different at the stable phase of growth (Figure 2A). Our results confirmed that $S$. Derby could survive at $\mathrm{pH} 4.0$, and previous studies also indicated that Salmonella could survive in the SCV at a pH of 4.0-5.0 [16,17]. Therefore, we used a genome-wide screen method $\mathrm{Tn}$-seq to explore the fitness of $S$. Derby $14 \mathrm{~T}$ in the acidic environment. The results showed that 35 genes were identified with a significantly diminished or greater abundance of insertions in the LB medium at pH 4.0 (Table 4), indicating these genes were involved in $S$. Derby $14 \mathrm{~T}^{\prime} \mathrm{s}$ acid stress response.

The 35 genes identified by Tn-seq were divided into five major functional groups, i.e., TCS, RIP system, CRISPR system, transport protein, and metabolism (Table 4) to obtain a better understanding of the genes involved in the acid stress. TCS can sense changes in the environment and regulate downstream genes' expression in response to environmental changes [45]. The PhoP/PhoQ TCS could respond to the low $\mathrm{Mg}^{2+}$, low $\mathrm{pH}$, and cationic antimicrobial peptides in E. coli, Shigella flexneri, and S. Typhimurium [46-48]. The PhoP/PhoQ and its regulator protein MgrB were also identified as involved in the acid stress response of $S$. Derby $14 \mathrm{~T}$ (Table 4). During the stress conditions, activated $\sigma^{\mathrm{E}}$ was released by RIP, which is a crucial regulator of the extracytoplasmic stress response and virulence [44]. The activity of $\sigma^{\mathrm{E}}$ could be induced by acid stress in $S$. Typhimurium [22], indicating that the RIP system may also play an important role in acid resistance in $S$. Derby $14 \mathrm{~T}$. The fluoride ion transporter $\mathrm{CrcB}$ and $\mathrm{H}^{+} / \mathrm{Cl}^{-}$exchange transporter $\mathrm{ClcA}$, could promote the extrusion of $\mathrm{H}^{+}$and maintain the survival of foodborne pathogens under extreme acid stress $[49,50]$. Our results also showed that the expression of $c l c A$ was induced at $\mathrm{pH} 4.0$ (Figure 3), and the growth curve of $\triangle c l c A$ was decreased compared to the WT at pH 4.0 (Figure 4). Our qRT-PCR results also showed that the casC, casE, clcA, and $m g r B$ were significantly increased at $\mathrm{pH} 4.0$ (Figure 3), indicating that acid stress could induce these genes' expression.

The function of TCS CPxAR in acid stress response and virulence was investigated in $S$. Derby 14T. The results showed that the growth curves of $\triangle c p x A$ mutant strain exhibited growth defects compared to WT under the stress condition of $\mathrm{pH} 4.0$ (Figure 5A). Furthermore, $\triangle c p x A$ and $\triangle c p x R$ strains' survival ability were significantly decreased compared to the WT after treatment at $\mathrm{pH} 4.0$ (Figure $5 \mathrm{~B}$ ). The adhesion and invasion rate of the $\Delta c p x R$ strain was significantly decreased compared to the WT (Figure 5C,D). Previous studies also showed that TCS CpxAR could directly sense acidic conditions to regulate the expression of $f a b A B$ in E. coli [41], and contributes to stress resistance and virulence in Actinobacillus pleuropeumoniae [51]. Moreover, the CpxAR-mediated envelope stress response plays a crucial role in the gut infection of $S$. Typhimurium [52]. Different growth rate and adhesion and invasion abilities of the $\triangle c p x R$ and $\triangle c p x A$ strains were observed in this study, these results suggested that other kinase(s) might interplay with the CpxAR TCS in S. Derby 14T [53-55]. These results indicated that CpxAR plays a vital role in the acid stress response and virulence of $S$. Derby 14T, even though the expression level of $c p x A$ and $c p x R$ showed no significant difference from WT cultured at $\mathrm{pH} 4.0$ compared to $\mathrm{pH} 7.0$ (Figure 3 ). This result may be due to the function of TCS being dependent on the transmission of the phosphate group. Thus, we speculate that CpxAR regulation of the acid stress response may depend on the post-translational, not transcriptional level in S. Derby $14 \mathrm{~T}$.

The expression of casC and casE was significantly upregulated under the low $\mathrm{pH}$ condition (Figure 3), and the survival ability of $\triangle c a s C$ and $\triangle c a s E$ was decreased compared to the WT at pH 4.0 (Figure 6B). These results suggest that CasC and CasE may participate in the regulation of acid stress of $\mathrm{S}$. Derby. The cas $C$ and $\operatorname{cas} E$ genes belonged to the type I-E CRISPR-Cas system, and previous studies of this system focused on virulence. A study in S. Enteritidis showed that the type I-E CRISPR-Cas system could regulate the expression of biofilm-forming-related genes and the type three secretion system (T3SS), and the invasion capacity of $\Delta$ cas3 to the host cells was also reduced [56]. The ability of Salmonella resistance to the low $\mathrm{pH}$ environment was beneficial to the survival of Salmonella in the cells [18]. Thus, we can assume that the CasC and CasE proteins' regulation of acid stress may contribute to the host cell infection of $S$. Derby. 


\section{Conclusions}

In summary, the whole genome sequence of $S$. Derby $14 \mathrm{~T}$ was determined, and 581 genes of the total 4579 genes were identified as the essential genes. Moreover, we have identified 35 genes that could potentially affect the survival ability of $S$. Derby in the low $\mathrm{pH}$ condition ( $\mathrm{pH} 4.0$ ). We have confirmed that TCS CpxA/R, ClcA, and CasC/CasE play an essential role in the resistance to acid stress. Nevertheless, functions of these genes in virulence of $S$. Derby need to be explored further.

Author Contributions: Conceptualization, D.G. and Y.Z.; Data curation, D.G. and H.X.; Formal analysis, D.G., H.X., X.Y., J.Y., X.X., Y.H., M.L., and Y.Z.; Funding acquisition, Y.Z. and X.J.; Methodology, D.G. and M.L.; Project administration, Z.P., Y.Z., and X.J.; Resources, X.Y., X.Z., Z.P., and X.J.; Software, Y.Z.; Writing—original draft, D.G., H.X., and Y.Z.; Writing—review \& editing, D.G. and Y.Z. All authors have read and agreed to the published version of the manuscript.

Funding: This research was funded by the Natural Science Foundation of Jiangsu Province, grant number BK20180911.

Institutional Review Board Statement: Not applicable.

Informed Consent Statement: Not applicable.

Data Availability Statement: The genome sequence and Tn-seq data were deposited in the CNGB database under the Bioproject accession no. CNP0001625.

Acknowledgments: We thank Lawrence Berkeley National Laboratory for providing the plasmid pKWM2.

Conflicts of Interest: The authors declare no conflict of interest.

\section{References}

1. Simon, S.; Trost, E.; Bender, J.; Fuchs, S.; Flieger, A. Evaluation of WGS based approaches for investigating a food-borne outbreak caused by Salmonella enterica serovar Derby in Germany. Food Microbiol. 2018, 71, 46-54. [CrossRef] [PubMed]

2. Sévellec, Y.; Granier, S.A.; Hello, S.L.; Weill, F.X.; Cadel-Six, S. Source Attribution Study of Sporadic Salmonella Derby Cases in France. Front. Microbiol. 2020, 11, 889. [CrossRef]

3. Sévellec, Y.; Felten, A.; Radomski, N.; Granier, S.A.; Hello, S.L.; Petrovska, L.; Mistou, M.Y.; Cadel-Six, S. Genetic Diversity of Salmonella Derby from the Poultry Sector in Europe. Pathogens 2019, 8, 46. [CrossRef]

4. European Food Safety Authority and European Centre for Disease Prevention and Control. The European Union One Health 2018 Zoonoses Report. EFSA J. 2019, 17, 5956. [CrossRef]

5. Yann, S.; Marie-Léone, V.; Granier, S.A.; Renaud, L.; Carole, F.; Simon, L.H.; Michel-Yves, M.; Sabrina, C.S. Polyphyletic Nature of Salmonella enterica Serotype Derby and Lineage-Specific Host-Association Revealed by Genome-Wide Analysis. Front. Microbiol. 2018, 9, 891. [CrossRef]

6. Zheng, H.; Hu, Y.; Li, Q.; Tao, J.; Cai, Y.; Wang, Y.; Li, J.; Zhou, Z.; Pan, Z.; Jiao, X. Subtyping Salmonella enterica serovar Derby with multilocus sequence typing (MLST) and clustered regularly interspaced short palindromic repeats (CRISPRs). Food Control 2017, 73, 474-484. [CrossRef]

7. Diemert, S.; Yan, T. Municipal wastewater surveillance reveals high community disease burden of rarely reported and possibly subclinical Salmonella Derby strain. Appl. Environ. Microbiol. 2020, 86, e00814-e00820. [CrossRef] [PubMed]

8. Hayward, M.R.; Jansen, V.; Woodward, M.J. Comparative genomics of Salmonella enterica serovars Derby and Mbandaka, two prevalent serovars associated with different livestock species in the UK. BMC Genom. 2013, 14, 365. [CrossRef] [PubMed]

9. Cao, L.; Wang, J.; Sun, L.; Kong, Z.; Wu, Q.; Wang, Z. Transcriptional analysis reveals the relativity of acid tolerance and antimicrobial peptide resistance of Salmonella. Microb. Pathog. 2019, 136, 103701. [CrossRef]

10. Howden, C.W.; Hunt, R.H.; Howden, C.W.; Hunt, R.H. Relationship between gastric secretion and infection. Gut 1987, 28, 96-107. [CrossRef]

11. Dykhuizen, R.S.; Frazer, R.; Duncan, C.; Smith, C.C.; Golden, M.; Benjamin, N.; Leifert, C. Antimicrobial effect of acidified nitrite on gut pathogens: Importance of dietary nitrate in host defense. Antimicrob. Agents Chemother. 1996, 40, 1422-1425. [CrossRef] [PubMed]

12. Smith, J.L. The role of gastric acid in preventing foodborne disease and how bacteria overcome acid conditions. J. Food Prot. 2003, 66, 1292-1303. [CrossRef] [PubMed]

13. Denbesten, L. Gastrointestinal Disease: Pathophysiology, Diagnosis, Management. Ann. Surg. 1984, 200, S0025-S6196.

14. Bird, T.; Hall, M.R.; Schade, R.O. Gastric histology and its relation to anaemia in the elderly. Gerontology 1977, 23, 309-321. [CrossRef] 
15. Cevallos-Almeida, M.; Martin, L.; Houdayer, C.; Rose, V.; Guionnet, J.M.; Paboeuf, F.; Denis, M.; Kerouanton, A. Experimental infection of pigs by Salmonella Derby, $S$. Typhimurium and monophasic variant of $S$. Typhimurium: Comparison of colonization and serology. Vet. Microbiol. 2019, 231, 147-153. [CrossRef]

16. Rathman, M.; Sjaastad, M.D.; Falkow, S. Acidification of phagosomes containing Salmonella Typhimurium in murine macrophages. Infect. Immun. 1996, 64, 2765-2773. [CrossRef] [PubMed]

17. Alpuche, A.C.M.; Swanson, J.A.; Loomis, W.P.; Miller, S.I. Salmonella Typhimurium activates virulence gene transcription within acidified macrophage phagosomes. Proc. Natl. Acad. Sci. USA 1992. [CrossRef]

18. Choi, J.; Groisman, E.A. Acidic $\mathrm{pH}$ sensing in the bacterial cytoplasm is required for Salmonella virulence. Mol. Microbiol. 2016, 101, 1024-1038. [CrossRef] [PubMed]

19. Lang, C.; Zhang, Y.; Mao, Y.; Yang, X.; Wang, X.; Luo, X.; Dong, P.; Zhu, L. Acid tolerance response of Salmonella during simulated chilled beef storage and its regulatory mechanism based on the PhoP/Q system. Food Microbiol. 2021, 95, 103716. [CrossRef]

20. Bearson, B.L.; Wilson, L.; Foster, J.W. A low pH-inducible, PhoPQ-dependent acid tolerance response protects Salmonella Typhimurium against inorganic acid stress. J. Bacteriol. 1998, 180, 2409-2417. [CrossRef] [PubMed]

21. Quinn, H.J.; Cameron, A.D.; Dorman, C.J. Bacterial regulon evolution: Distinct responses and roles for the identical OmpR proteins of Salmonella Typhimurium and Escherichia coli in the acid stress response. PLoS Genet. 2014, 10, e1004215. [CrossRef]

22. Muller, C.; Bang, I.-S.; Velayudhan, J.; Karlinsey, J.; Papenfort, K. Acid stress activation of the $\sigma$ E stress response in Salmonella enterica serovar Typhimurium. Mol. Microbiol. 2009, 71, 1228-1238. [CrossRef] [PubMed]

23. Audia, J.P.; Foster, J.W. Acid Shock Accumulation of Sigma S in Salmonella enterica Involves Increased Translation, Not Regulated Degradation. J. Mol. Microbiol. Biotechnol. 2003, 5, 17-28. [CrossRef] [PubMed]

24. Alvarez-Ordonez, A.A.; Begley, M.; Prieto, M.; Messens, W.; Hill, C. Salmonella spp. survival strategies within the host gastrointestinal tract. Microbiology 2011, 157, 3268-3281. [CrossRef]

25. Ren, J.; Sang, Y.; Ni, J.; Tao, J.; Lu, J.; Zhao, M.; Yao, Y.F. Acetylation Regulates Survival of Salmonella enterica Serovar Typhimurium under Acid Stress. Appl. Environ. Microbiol. 2015, 81, 5675-5682. [CrossRef] [PubMed]

26. Ryan, D.; Pati, N.B.; Ojha, U.K.; Padhi, C.; Suar, M. Global Transcriptome and Mutagenic Analyses of the Acid Tolerance Response of Salmonella enterica Serovar Typhimurium. Appl. Environ. Microbiol. 2015, 81, 8054-8065. [CrossRef] [PubMed]

27. Kenney, L.J. The role of acid stress in Salmonella pathogenesis. Curr. Opin. Microbiol. 2019, 47, 45-51. [CrossRef]

28. Lee, S.A.; Dunne, J.; Febery, E.; Wilcock, P.; Mottram, T.; Bedford, M.R. Superdosing phytase reduces real-time gastric pH in broilers and weaned piglets. Br. Poult Sci. 2018, 59, 330-339. [CrossRef]

29. Aluthge, N.D.; van Sambeek, D.M.; Carney-Hinkle, E.E.; Li, Y.S.S.; Fernando, S.C.; Burkey, T.E. BOARD INVITED REVIEW: The pig microbiota and the potential for harnessing the power of the microbiome to improve growth and health. J. Anim. Sci. 2019, 97, 3741-3757. [CrossRef] [PubMed]

30. Chesson, A. 6-supplemeary enzymes to improve the utilization of pig and poultry diets. Recent Adv. Anim. Nutr. 1987, 71-89. [CrossRef]

31. Wetmore, K.M.; Price, M.N.; Waters, R.J.; Lamson, J.S.; He, J.; Hoover, C.A.; Blow, M.J.; Bristow, J.; Butland, G.; Arkin, A.P.; et al. Rapid quantification of mutant fitness in diverse bacteria by sequencing randomly bar-coded transposons. MBio 2015, 6, e00306-e00315. [CrossRef]

32. Liang, W.L.; Wang, S.X.; Yu, F.G.; Zhang, L.J.; Qi, G.M.; Liu, Y.Q.; Gao, S.Y.; Kan, B. Construction and evaluation of a safe, live, oral Vibrio cholerae vaccine candidate, IEM108. Infect. Immun. 2003, 71, 5498-5504. [CrossRef] [PubMed]

33. Wang, S.Y.; Lauritz, J.; Jass, J.; Milton, D.L. A ToxR homolog from Vibrio anguillarum serotype O1 regulates its own production, bile resistance, and biofilm formation. J. Bacteriol. 2002, 184, 1630-1639. [CrossRef] [PubMed]

34. Wick, R.R.; Judd, L.M.; Gorrie, C.L.; Holt, K.E. Unicycler: Resolving bacterial genome assemblies from short and long sequencing reads. PLoS Comput. Biol. 2017, 13, e1005595. [CrossRef] [PubMed]

35. Seemann, T. Prokka: Rapid prokaryotic genome annotation. Bioinformatics 2014, 30, 2068-2069. [CrossRef]

36. Huerta-Cepas, J.; Szklarczyk, D.; Forslund, K.; Cook, H.; Heller, D.; Walter, M.C.; Rattei, T.; Mende, D.R.; Sunagawa, S.; Kuhn, M.; et al. eggNOG 4.5: A hierarchical orthology framework with improved functional annotations for eukaryotic, prokaryotic and viral sequences. Nucleic Acids Res. 2016, 44, D286-D293. [CrossRef]

37. Grant, J.R.; Stothard, P. The CGView Server: A comparative genomics tool for circular genomes. Nucleic Acids Res. 2008, 36, W181-W184. [CrossRef] [PubMed]

38. Yang, G.; Billings, G.; Hubbard, T.P.; Park, J.S.; Yin Leung, K.; Liu, Q.; Davis, B.M.; Zhang, Y.; Wang, Q.; Waldor, M.K. Time-Resolved Transposon Insertion Sequencing Reveals Genome-Wide Fitness Dynamics during Infection. MBio 2017, 8, e01581-e01617. [CrossRef] [PubMed]

39. DeJesus, M.A.; Ambadipudi, C.; Baker, R.; Sassetti, C.; Ioerger, T.R. TRANSIT-A Software Tool for Himar1 TnSeq Analysis. PLoS Comput. Biol. 2015, 11, e1004401. [CrossRef] [PubMed]

40. Guo, Y.; Gu, D.; Huang, T.; Cao, L.; Zhu, X.; Zhou, Y.; Wang, K.; Kang, X.; Meng, C.; Jiao, X.; et al. Essential role of Salmonella Enteritidis DNA adenine methylase in modulating inflammasome activation. BMC Microbiol. 2020, 20, 226. [CrossRef] [PubMed]

41. Xu, Y.; Zhao, Z.; Tong, W.; Ding, Y.; Liu, B.; Shi, Y.; Wang, J.; Sun, S.; Liu, M.; Wang, Y.; et al. An acid-tolerance response system protecting exponentially growing Escherichia coli. Nat. Commun. 2020, 11, 1496. [CrossRef] [PubMed] 
42. Nunez-Hernandez, C.; Tierrez, A.; Ortega, A.D.; Pucciarelli, M.G.; Godoy, M.; Eisman, B.; Casadesus, J.; Garcia-del Portillo, F. Genome expression analysis of nonproliferating intracellular Salmonella enterica serovar Typhimurium unravels an acid $\mathrm{pH}-$ dependent PhoP-PhoQ response essential for dormancy. Infect. Immun. 2013, 81, 154-165. [CrossRef] [PubMed]

43. Eguchi, Y.; Ishii, E.; Hata, K.; Utsumi, R. Regulation of acid resistance by connectors of two-component signal transduction systems in Escherichia coli. J. Bacteriol. 2011, 193, 1222-1228. [CrossRef]

44. Gu, D.; Guo, M.; Yang, M.; Zhang, Y.; Zhou, X.; Wang, Q. A sigmaE-Mediated Temperature Gauge Controls a Switch from LuxR-Mediated Virulence Gene Expression to Thermal Stress Adaptation in Vibrio alginolyticus. PLoS Pathog. 2016, 12, e1005645. [CrossRef]

45. Tierney, A.R.; Rather, P.N. Roles of two-component regulatory systems in antibiotic resistance. Future Microbiol. 2019, 14, 533-552. [CrossRef]

46. Lippa, A.M.; Goulian, M. Feedback inhibition in the PhoQ/PhoP signaling system by a membrane peptide. PLoS Genet. 2009, 5, e1000788. [CrossRef] [PubMed]

47. Salazar, M.E.; Podgornaia, A.I.; Laub, M.T. The small membrane protein MgrB regulates PhoQ bifunctionality to control PhoP target gene expression dynamics. Mol. Microbiol. 2016, 102, 430-445. [CrossRef]

48. Lin, Z.W.; Cai, X.; Chen, M.L.; Ye, L.; Wu, Y.; Wang, X.F.; Lv, Z.H.; Shang, Y.P.; Qu, D. Virulence and Stress Responses of Shigella flexneri Regulated by PhoP/PhoQ. Front. Microbiol. 2018, 8, 2689. [CrossRef]

49. Accardi, A.; Miller, C. Secondary active transport mediated by a prokaryotic homologue of ClC Cl-channels. Nature 2004, 427, 803-807. [CrossRef]

50. Iyer, R.; Iverson, T.M.; Accardi, A.; Miller, C. A biological role for prokaryotic ClC chloride channels. Nature 2002, 419, 715-718. [CrossRef]

51. Yan, K.; Liu, T.; Duan, B.; Liu, F.; Cao, M.; Peng, W.; Dai, Q.; Chen, H.; Yuan, F.; Bei, W. The CpxAR Two-Component System Contributes to Growth, Stress Resistance, and Virulence of Actinobacillus pleuropneumoniae by Upregulating wecA Transcription. Front. Microbiol. 2020, 11, 1026. [CrossRef] [PubMed]

52. Fujimoto, M.; Goto, R.; Haneda, T.; Okada, N.; Miki, T. Salmonella enterica Serovar Typhimurium CpxRA Two-Component System Contributes to Gut Colonization in Salmonella-Induced Colitis. Infect. Immun. 2018, 86, e00280-e00318. [CrossRef] [PubMed]

53. De la Cruz, M.A.; Pérez-Morales, D.; Palacios, I.J.; Fernández-Mora, M.; Calva, E.; Bustamante, V.H. The two-component system CpxR/A represses the expression of Salmonella virulence genes by affecting the stability of the transcriptional regulator HilD. Front. Micriobiol. 2015, 6, 807. [CrossRef]

54. Spinola, S.M.; Fortney, K.R.; Baker, B.; Janowicz, D.M.; Zwickl, B.; Katz, B.P.; Blick, R.J.; Munson, R.S., Jr. Activation of the CpxRA system by deletion of cpxA impairs the ability of Haemophilus ducreyi to infect humans. Infect. Immun. 2010, 78, 3898-3904. [CrossRef]

55. Matter, L.B.; Ares, M.A.; Abundes-Gallegos, J.; Cedillo, M.L.; Yáñez, J.A.; Martínez-Laguna, Y.; De la Cruz, M.A.; Girón, J.A. The CpxRA stress response system regulates virulence features of avian pathogenic Escherichia coli. Environ. Microbiol. 2018, 20, 3363-3377. [CrossRef] [PubMed]

56. Cui, L.; Wang, X.; Huang, D.; Zhao, Y.; Feng, J.; Lu, Q.; Pu, Q.; Wang, Y.; Cheng, G.; Wu, M.; et al. CRISPR-cas3 of Salmonella Upregulates Bacterial Biofilm Formation and Virulence to Host Cells by Targeting Quorum-Sensing Systems. Pathogens 2020, 9, 53. [CrossRef] [PubMed] 